\title{
КОНЦЕПТУАЛЬНІ ЗАСАДИ ПРОЕКТУВАННЯ ВЕБ-ПРЕЗЕНТАЦІЙ НА ПРИКЛАДІ МЕДИЧНИХ НАУКОВИХ ПУБЛІКАЦІЙ 3 ВИКОРИСТАННЯМ СИСТЕMИ AS4U
}

\author{
К. І. Ільканич, В. Ю. Майхер \\ Львівський національний державний медичний університет імені Данила Галицького
}

\begin{abstract}
Проаналізовано використання сучасних інформаційних веб-технологій, які істотно впливають на етап розвитку інформаційного поля в Україні. Використання інноваційних інформаційних систем та технологій для проектування та експлуатації веб-сайтів дає можливість істотно спростити процес обміну інформацією, адже на сьогодні йдеться про актуальність інформації та її доступність.
\end{abstract}

Ключові слова: інформаційні системи для створення веб-сайтів, AS4u, Public4u, Galery4u, File4u, Admin4u.

\section{КОНЦЕПТУАЛЬНЫЕ ОСНОВЫ ПРОЕКТИРОВАНИЯ ВЕБ-ПРЕЗЕНТАЦИЙ НА ПРИМЕРЕ МЕДИЦИНСКИХ НАУЧНЫХ ПУБЛИКАЦИЙ С ИСПОЛЬЗОВАНИЕМ СИСТЕМЫ AS4U}

\author{
К. И. Ильканич, В. Ю. Майхер \\ Львовский национальный государственный медицинский университет \\ имени Данила Галицкого
}

\begin{abstract}
Проанализировано использование современных информационных веб-технологий, существенно влияющих на этап развития информационного поля в Украине. Использование инновационных информационных систем и технологий для проектирования и эксплуатации веб-презентаций позволяет значительно упростить процесс обмена информацией, ведь на сегодняшний день речь идет об актуальности информации и ее доступности.
\end{abstract}

Ключевые слова: информационные системы для создания веб-сайтов, AS4u, Public4u, Galery4u, File4u, Admin4u.

\section{CONCEPTUAL FRAMEWORK WEB DESIGN PRESENTATIONS ON THE EXAMPLE OF MEDICAL SCIENTIFIC PUBLICATIONS WITH THE USE OF AS4U}

\author{
K. I. Ilkanych, V. Yu. Maikher
}

\section{Danylo Galicky Lviv National Medical University}

58 It was analyzed the usage of modern information web technologies that significantly affect the stage of development of information field in Ukraine. Using innovative information systems and technologies for the design and operation of websites can significantly simplify the exchange of information, because today we are talking about the relevance of information and its availability.

Key words: information system for building web sites, AS4u, Public4u, Galery4u, File4u, Admin4u.

Вступ. Короткий аналіз останніх досліджень та публікацій в Україні показує, що інтернет-технології широко використовуються в медицині: передача інформації із застосуванням інформаційних технологій, веб-технології, створення так званих інтелект-карт, комп'ютерна підтримка діяльності медичних закладів, комп'ютерна діагностика та обмін інформаційними ресурсами (відео-, фото-, аудіофайли, посилання, презентації).

Формування методики оцінки ефективності застосування інформаційних технологій на етапах їх впровадження і експлуатації підприємствами та організаціями визначає методичні підходи до вибору систем та інформаційних технологій, що вимагає відповідного організаційного підходу та механізму формування та реалізації IT-стратегії 
в діяльності підприємств 3 оцінкою іiї ефективності. Це спонукає до створення та впровадження комплексної автоматизованої системи управління діяльністю, створення алгоритму впровадження системи та визначення методичних підходів до оцінки ефективності інвестицій у системи.

Як показує аналіз інформаційного поля в Україні, наразі недостатньо доступної актуальної інформації іноземними мовами на веб-презентаціях. В цьому аспекті слід зазначити, що виникають проблеми через недосконалість морально застарілих інформаційних технологій, за допомогою яких навіть зараз створюються сайти. Такі системи мають багато незручностей не тільки під час створення сайту, а й під час його експлуатації. Приміром, вони передбачають право управління сайтом тільки для адміністратора, який має доступ до коду та всіх об'єктів сайту. Натомість необхідне застосування сучасних систем (платформ), які завдяки спеціальним редакційним системам та окремим модулям адміністрування сайту дають можливість оновлювати інформацію веб-сайту без послуг програміста, а мають можливість розподілу ролей та доступів користувачів у процесі наповнення контентом, що пришвидшує процес оновлення інформації на сайті, оскільки наповнювати сайт контентом можуть кілька осіб, приміром, один програміст-адміністратор та звичайні редактори, які мають доступ тільки до своїх підрозділів на сайті, при цьому редагують текст, вставляють графічні об'єкти (фото, відео), змінюють структуру сайту, додаючи свої підрозділи тощо.

Мета дослідження: обгрунтування концептуальних засад та принципів створення сучасних веб-презентацій, які істотно впливають на процес експлуатації веб-сайтів, у тому числі в медичних закладах.

Концептуалізація дослідження. Редакційна система AS4u дає можливість цілісного управління www-презентаціями від налаштування вигляду до створення структури та подання розділу, категорії, статті. Ї̈̈ переваги також в тому, що наповнювати сайт контентом можуть кілька осіб,

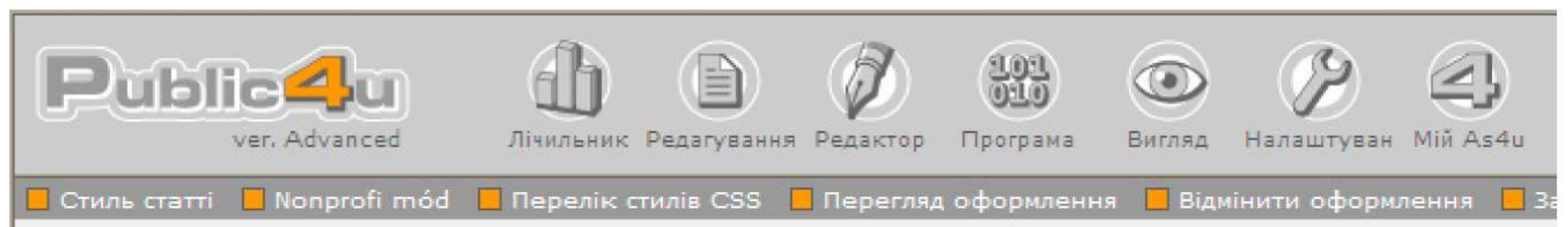

\title{
Редагувати стиль загального вигляду
}

\author{
Виберіть відділ: hlavni strana $\vee$ Очистити вигляд
}

\section{ВИБЕРІТЬ СТИЛЬ:}

Elnhálnímactavení

body

a

a:hover

input

select

fieldset

legend

ul

ol

li

div.stranka

div.zahlavi obal

div.pomocny 1

div.pomocny 2

div.oba_sloupce

div.sloupec_navigace_obal

div.pravy_sloupec_obal

div.cely_clanek

div.cleaner

div.chyba
ВКАЖІТЬ ПАРАМЕТРИ:

\begin{tabular}{l|l|}
\hline background-color & $\# 660000$ \\
\hline background-attachment & url(http//Www_as4u_cz/galerie/ \\
\hline background-image & top left \\
\hline background-position & repeat-x \\
\hline background-repeat &.- \\
\hline border-style & \\
\hline border-color & \\
\hline border-width & \\
\hline
\end{tabular}

Рис.1. Редакційна система Public4u 
ЛЬВІВСЬКИЙ МЕДИЧНИЙ ЧАСОПИС

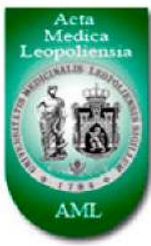

Acta

Medica

Leopoliensia

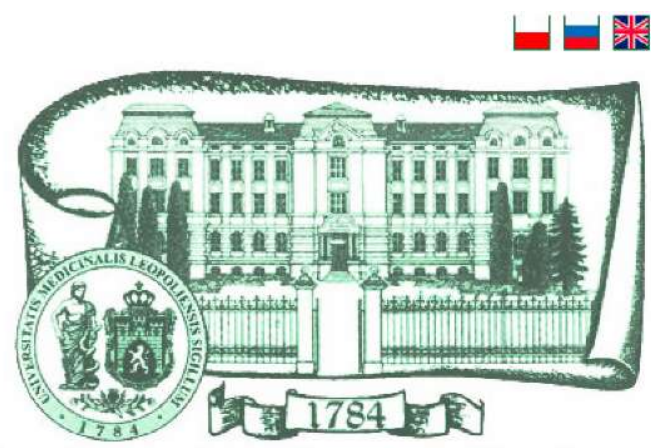

Засновник часопису: Львівський нашіональний медичний універсигет імені Данила Галицького

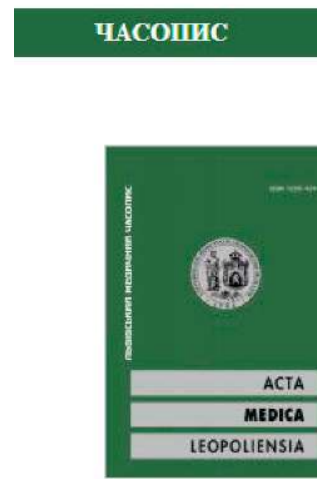
РЕЙтинГ APXIB ПІयІाИСКА

ABTOРAM

КОНТАКТИ

\begin{tabular}{l}
\hline Пошук \\
\hline \\
\hline Новини \\
\hline 3.2 .2014 \\
Набір статей у часопис №3, \\
$\mathbf{2 0 1 4}$ р. триватиме до 1.06.2014. \\
3.2.2014 \\
Просимо звернути увагу на \\
обов'язкове подання до пакету \\
документів "Декларації етики \\
публікації статті" та \\
"Повідом.лення про конфлікт \\
інтересів".
\end{tabular}

Рис. 2. Головна сторінка веб-презентації медичного часопису

попередньо отримавши роль та права доступу завдяки спеціальному модулю адміністрування сайту Admin4u в системі.

При цьому для наповнення контентом у системі $\mathrm{AS} 4 \mathrm{u}$ не обов'язкове знання програмування, достатньо спеціаліста з редагування тексту в текстовому редакторі, адже інтерфейс редактора Public4u в системі $\mathrm{AS} 4 \mathrm{u}$ простий, інтуїтивно-зрозумілий для користувача, має зручне середовище, локалізоване кількома іноземними мовами, в тому числі українською і російською.

Такий підхід до управління контентом значно здешевлює роботу над сайтом на етапі експлуатації, адже кожен підрозділ медичного закладу сам оновлює інформацію свого сектору, а не користується послугами програміста-адміністратора. Редакційна система має можливості редагування, аналогічні MS Word, і тільки адміністратор має можливість писати в XHTML, або програмувати v РНР. Це особливо важливо для підприємств та організацій з великою кількістю підрозділів, оскільки один адміністратор не встигатиме вносити та оновлювати інформацію, тим більше, що програміст-адміністратор має інші обов'язки: реконструкція сайту, оновлення дизайну тощо. Отже, завдяки новітнім системам, таким як AS4u, в структурі сайту може працювати кілька осіб, які мають доступ тільки до своєї сторінки, при цьому можуть створювати на сайті свої підрозділи тощо.

Професійна видавнича та редакційна система призначена для створення веб-презентацій на інтранетних або інтернетних порталах всіх типів. Основними перевагами видавничої та редакційної системи Public4u (рис. 1) є висока оптимізація пошуку (SEO), завдяки чому веб-сторінки потраплять на головні позиції пошукових серверів. Інша перевага системи - можливість налаштування за побажанням замовника, під'єднання до зовнішніх систем та доступ до доповнення власних функцій.

Редакційна система містить налаштування для автоматичного створення галереї з можливістю перегляду слайд-шоу. Рисунки вставляються до віртуальних каталогів, до яких є можливість створювати написи та опис. Також є можливість до кожної картинки (фото) дефінувати ключові слова, GPS-позицію. В редакційній системі $\epsilon$ можливість часткового редагування (збільшення, зменшення) рисунків (фото). 


\section{Архів номерів часопису}

\begin{tabular}{l} 
Новини \\
3.2.2014 \\
Набір статей \\
2014 р. трива \\
3.2 .2014 \\
Просимо зве] \\
обов'язкове 1 \\
документів " \\
публікації ст: \\
"Повідом.тен \\
інтересів". \\
3.2.2014 \\
Заверпено н: \\
часопис 2014 \\
Всі новини \\
Відправити нови \\
пошту: \\
\hline
\end{tabular}

\begin{tabular}{|c|c|c|c|c|}
\hline Рік видання & \multicolumn{4}{|c|}{ Номер } \\
\hline 2013 & №1 & Nㅡ2 & $\underline{N 233}$ & №4 \\
\hline 2012 & №1 & $\underline{\text { №2 }}$ & №3 & №4 \\
\hline 2011 & $\underline{\text { №1 }}$ & $\underline{\text { №2 }}$ & $\underline{\text { №3 }}$ & №4 \\
\hline 2010 & №1 & №2 & №3 & $\underline{\text { №4 }}$ \\
\hline 2009 & №1 & №2 & №3 & №4 \\
\hline
\end{tabular}

Рис. 3. Електронний архів номерів періодичного видання

За результатами наукового аналізу та пошуку нових підходів до інформатизації медичних закладів та нових технологій проектування й розробки веб-презентацій для медичних періодичних видань було проведено: розробку структури моделі інформаційного ресурсу для реалізації інформатизації послуг часопису з використанням сучасних IT-технологій; формування методики оцінки ефективності застосування інформаційних технологій на етапах їх впровадження та експлуатації; створення алгоритму програмного продукту та механізму впровадження і визначення методичних підходів до оцінки ефективності інвестицій у IT-системи; засобами програмного продукту AS4u [10] розроблено та впроваджено проект веб-ресурсу www.aml.lviv. ua - інтернет-сайт фахового видання «Acta Medica Leopoliensia / Львівський медичний часопис», засновником якого $є$ Львівський національний медичний університет імені Данила Галицького. Першу сторінку цього сайту подано на рис. 2.

Важливим елементом сайту $є$ архів номерів. За статистичними даними, «розміщення статті в інтернеті у відкритому доступі збільшує кількість «паперових» посилань на неї у 3-5 разів» [6], що істотно впливає на збільшення такого важливого показника якісної оцінки наукових досліджень як індекс цитувань. На рис. 3 подано фрагмент наповнення розробленого сайту.

Система Public4u, засобами якої було реалізовано проект пропонованого веб-ресурсу, є редактором із величезними можливостями, який не вимагає особливих підходів та дає можливість редагувати веб-презентацію в режимі online без послуг програміста, що сприяє швидкому оновленню інформації.

Результати та їх обговорення. Підсумовуючи сказане, можна дійти висновку, що проблеми в інформаційному просторі можна вирішити шляхом використання новітніх інформаційних технологій створення згаданої вище системи інформаційного простору, завданням якого $є$ збір та накопичення актуальної інформації.

За результатами виконаної роботи було запропоновано новий підхід до розробки інтернет-ресурсу наукового періодичного видання, який сприяє спрощенню діалогу між авторами та редколегією журналу. Входження наукового медичного періодичного видання в інтернет-простір у якості окре- 
мого ресурсу вимагає збільшення вимогливості до наукового рівня публікацій, а також підвищення ефективності наукових досліджень та впровадження результатів наукових розробок.

Висновок. Кількамовна реалізація сайту сприятиме активнішій підготовці публікацій інозем- ними мовами та більш широкому представленню вітчизняної наукової періодики у міжнародних інформаційних базах і включення іiі у світові наукометричні бази, дасть можливість ширшого обговорення науковою спільнотою досліджень, представлених на шпальтах журналу.

\section{Література.}

1. Виноградова Е. А. Создание единого информационно-образовательного пространства в образовательном учреждении. ИКТ - новая технология управления в образовательном учреждении / Е. А. Виноградова. - Режим доступу: http://festival.1 september.ru/articles/538755/.

2. Новые педагогические и информационные технологии в системе образования: учеб. пособ. для студ. пед. вузов и системы повыш. квалиф. пед. кадров / Е. С. Полат, М. Ю. Бухаркина, М. В. Моисеева, А. Е. Петров / под ред. Е. С. Полат. - М. : Академия, 2000. - 272 с.

3. Мельниченко С. Ю. Інноваційні проблеми автоматизації управління бізнесом / С. Ю. Мельниченко. - Житомир, 2007. - С. 37-49.

4. Мельниченко С. Ю. Стратегії ІТ-технологій в освіті, економіці та екології / С. Ю. Мельниченко. - Харків, 2007. - 255 c.

5 Смульсон М. Л. Проектування дистанційних розвивальних середовищ. - Режим доступу: http://www.nbuv.gov. ua/e-journals/tri/2011_1/st1.pdf.

6. Р-інкон Україна [Електронний ресурс]. - Режим доступу: http://www.r-incon.com.ua. 